A general Meeting held in Brussels on 13 March 1948 decided to modify the statutes of the Institute on three points: its scope, its membership, its name.

It is now called the International Institute of Political and Social Sciences Concerning Countries of Differing Civilizations (previously The International Colonial Institute). Whereas under its original statutes the Institute could only accept as members those belonging to countries possessing colonies or colonizing their own territories, from now on the Institute will be constituted of members chosen from people of all nationalities, regardless of race or sex, who possess a thorough knowledge, theoretical or practical, of the problems with which it is its purpose to deal.

\title{
Chaka the Zulu ${ }^{\mathrm{I}}$
}

AN English translation of the original Sesuto novel by Thomas Mofolo was published by the International African Institute in $193 \mathrm{I}$. The book aroused wide interest at the time as an example of literary work of a high quality by an African. This edition is now out of print, but a shortened and simplified version, with six full-page illustrations, has now been issued by the Oxford University Press. The story is also being published in serial form in a magazine for teachers published by the Education Department, Southern Sudan.

\section{Wanga Yoane ${ }^{2}$}

A MANUSCRIPT written in the Nkunto-Mongo language by Bongelemba Natanaele, submitted for the Vernacular Essay Competition organized by this Institute in 1939, has been translated into English by the Rev. Herbert Smith and published by the United Christian Missionary Society, Indiana.

The book is autobiographical and gives an account of the author's childhood in the Belgian Congo, his education at the Congo Christian Institute, his conversion to Christianity, and his experiences as a teacher. Many children's games, proverbs, and fables are included.

\section{Towards the New Africa}

DURING the first post-war years the Uganda Society conceived the idea of a series of lectures and discussions which would serve to draw attention to the different aspects of Uganda's inevitable future development. The success of the series was such that the Society felt a wider public should be able to study the arguments put forward and they therefore published the lectures under the present title. Contributions are by both Africans and Europeans and cover a wide range of topics, including agricultural efficiency, malnutrition, and educational adaptation. The series concludes with a short review by a prominent business man entitled 'A business man looks at Africa'.

I Chaka the Zulu, by Thomas Mofolo. The English Reader's Library, London: Oxford University Press, 1949. Pp. I25, ill.

${ }^{2}$ Wanga Yoane of the Village of Yuli, written by Wanga, translated by Herbert Smith, illustrated by Rose Wright. Indianapolis: United Christian Missionary Society, 1948. Pp. I27.

3 Towards the New Africa, by Margaret Trowell and others. The Uganda Society, Kampala, 1949. $2 s$. 